\title{
DOES BORSA ISTANBUL INCORPORATE HERDING AND CALENDAR ANOMALIES? AN EMPIRICAL EVIDENCE
}

\author{
DOI: 10.17261/Pressacademia.2020.1189 \\ JBEF- V.9-ISS.1-2020(2)-p.12-27
}

Ahmet Mete Cilingirturk ${ }^{1}$, Meltem Ulusan Polat ${ }^{2}$, Handan Sumer Gogus ${ }^{3}$

${ }^{1}$ Marmara University, Faculty of Economics, Department of Econometrics, Istanbul, Turkey. acilingi@marmara.edu.tr, ORCID: 0000-0001-8677-7969

2Marmara University, Faculty of Business Administration, German-Speaking Program for BA, Istanbul, Turkey. meltem.ulusan@marmara.edu.tr, ORCID: 0000-0002-0673-5185

${ }^{3}$ Marmara University Faculty of Business Administration, German-Speaking Program for BA, Istanbul, Turkey. handans@yahoo.com, ORCID: 0000-0002-1408-9339

\begin{abstract}
Purpose- Anomalies and herding rather than individual rational decisions could be detected in capital markets. Such formations' enabling abnormal returns under volatility, may be of interest in respect of Turkish capital markets. This study analyzes the herd behavior and calendar anomalies in Borsa Istanbul (BIST) by generalizing the main index and the sectoral indices.

Methodology- The data set is based on the weekly closing prices, trading volume and the number of contracts of BIST-100 Index and 17 sectoral indices for the January 2012 to December 2016. A symmetric GARCH $(1,1)$ and an asymmetric SAARCH (1,1) models have been employed for a comparative analysis.

Findings- Since GARCH $(1,1)$ findings revealed a quiet weak simultaneous interaction between volatility and return, the research was deepened through employment of the SAARCH $(1,1)$ asymmetric estimation model, which revealed an increase in both trading volume and return when considering negative shocks. Hence, a significant herding in BIST has been confirmed. SAARCH $(1,1)$ model has detected day of the week (DoW) and a significant January effect, as well, while both estimation models have detected Ramadan effects.

Conclusion- It becomes apparent that there is a gap in the Turkish capital market-related combined studies on herding and calendar anomalies. The aim of this study, therefore, is to fill this gap, using analyses of the BIST-100 and sectoral indices. Main indices, consisting of blue-chips, are analyzed frequently; however, abnormal trading behaviors could be detected specifically on sectoral basis.
\end{abstract}

Keywords: Herding, calendar anomalies, GARCH, SAARCH, panel data analysis.

JEL Codes: G40, G41, G23

\section{INTRODUCTION}

Considering that individuals are affected by behavioral factors while taking investment decisions, Kahneman and Tversky (1979) developed Prospect Theory. This approach in the finance area contrasts with Fama's (1970) efficient market definition, highlighting irrational investors with heuristics and cognitive biases as against wealth maximization and a rational profile.

For various reasons, the existence of an inefficient market enables abnormal returns. Concordantly, anomalies and herd behavior rather than individual rational decisions can be detected on behalf of investors in capital markets.

Asking whether these anomalies implied profitable trading strategies, Thaler (1987) concluded that this was difficult to ascertain. He also emphasized that anomalies were interesting and worth investigating, even if it was not possible to make money from them. Developing this idea, such formations may be recognized as important for investors seeking abnormal returns by considering volatile structure of Turkish capital markets.

In the academic literature, anomalies are defined as the deviation of returns from the average and analyzed in different dimensions. In this study, calendar (seasonal) anomalies are considered. Calendar anomalies are market anomalies leading to systematically different behaviors of returns related with specific calendar periods. In this context, day of the week (DoW), 
post-holiday, Ramadan \& Zul-Hijjah (month of Eid al-Adha and Pilgrimage), January and December, the days of Federal Reserve (FED) and Central Bank of Turkey (CBT) monetary policy committee meetings, and semester holiday effects are analyzed according to the BIST-100 and BIST sectoral indices.

Herd behavior, an important topic in both finance and behavioral sciences, is also considered. This concept was initially introduced in Dr. Wilfred Trotter's (1916) work, "Instincts of the Herd in Peace and War". Much considered in psychology, herd behavior in the present context is characterized in terms of investors' imitating one another in capital markets rather than independently implementing their own decisions. The occurrence of herd behavior is particularly important for countries with individual investors targeting speculative returns with short-term-based investment horizons.

As it can be seen from the literature survey (below), calendar anomalies and herding are frequently considered separately, both in Turkey and in the international arena generally. This study analyzing these two phenomena in respect of BIST-100 and all sectoral indices has four main sections. Following the introduction, a comprehensive literature review is given in the second part, and a presentation of the methodology and study results comprises the third part, with the last section adding a conclusion.

\section{LITERATURE REVIEW}

There is a large volume of studies in both the national and international literature on herding and calendar anomalies. In this literature review, herding is covered first, calendar anomalies second, and finally studies involving both effects.

One of the main studies on herding to be made was that of Chan et al. (2000). They detected herd behavior in the US, HongKong, Japan, South Korea, and Taiwan capital markets over periods of between 180 and 420 months, with the time intervals found to vary from country to country. The findings of this analysis led the occurrence of herd behavior to be partially accepted in Japan, an advanced economy with a sophisticated financial sector, and significantly accepted in South Korea and Taiwan, which were treated as emerging countries.

Another comprehensive study, by Chiang et al., 2011 covered Australia, Hong-Kong, Japan, Singapore and the US as developed markets and China, Indonesia, Malesia, South Korea, Thailand and Taiwan as emerging markets. This study included data from 07.02.1997 to 12.31.2008, and herding was detected in both bull and bear market structures, with an impact that varied due to time. Herding was also found to be positively related to stock market performance but negatively related to market volatility.

Messis and Zapranis (2014) analyzed herding in the Athens Stock Exchange, where they identified serious differentiations in investor portfolios during herding periods. Accordingly, herding was found to have a contagiousness affect during crisis periods, with such economic conditions calling the efficacy of international portfolio diversification into doubt. There was also a linear relationship between herding and volatility; thus, herding can be regarded as an additional risk factor. A further study was conducted by Blasco et al. (2010), looking at volatility estimation and the design of investor decision-making processes in terms of herding. In this analysis, volatility was considered in three-dimensions, namely, as historical, realized and, implied. The results showed herding to have a linear impact on volatility even though the intensity is not always the same. Therefore, herding is a key factor in a volatile market during investment-based decision-making process.

It is consequential to identify the relationship between herding and volatility in emerging markets while contemplating their own unstable dynamics. Lao and Singh (2011) confirmed this by analyzing the China and Indian stock markets, underlining that herding is much more significant during periods of high volatility.

Wang (2008) covered 21 stock markets, grouped as developed, emerging Latin American, and emerging Asian. He concluded that there is a higher level of herding in emerging markets than developed markets, and he found the correlation of herding between two markets from the same group to be higher than that between two markets from different groups.

Another issue to be underlined is the association of herding with other capital market-coordinated factors. Cakan et al. (2019) have analyzed the relationship of herding in stock markets with speculative movements in commodity markets. Analyzing this for Russia, Brazil, and Turkey, they detected that speculative movements in global oil markets in Russia and Brazil led to a significant herd behavior among investors in these countries' stock markets. On this basis, they determined that investor behaviors in local markets can be designed and inspected by following commodity markets.

Another factor in the literature related with herding is that of trading volume. BenSaida et al. (2015) tested the US stock market, including all firms listed on Dow Jones Industrial Average, and detected no strong herding effect, but they did find that trading volume triggers herd behavior and that this is a mutual relationship. Boyd et al. (2016) analyzed herding and its resources and effects in the US futures markets by considering big and speculative traders for 2004-2009. They determined that the efficient dissemination of public information among investors suppresses herding. When analyzing the impact of 
trading systems, they identified a positive relationship between the numbers of investors trading in the open-outcry system and herding behavior. However, the herding relationship with trading volume and electronic trading platform was negative.

Reviewing the Turkish literature, Altay (2008) examined herding in the (old) Istanbul Stock Exchange (ISE) between January 1997 and February 2008 using two different methods. First, a cross-sectional analysis was conducted and no herding detected in the general or sectoral indices. Considering that this was mainly due to nonlinearity between cross-sectional absolute deviation and index-return, the analysis was deepened by analyzing the excessive high/low return rate and cross-sectional variation relationship. The findings for this indicated the relationship to be nonlinear, so this can be evaluated as a proof of herd behavior in the market. Another study in the ISE, made between 2000 and 2010 by Kapusuzoglu (2011), supported Altay's findings.

Kayalidere (2012) scrutinized herding in the ISE between January 1997 and July 2012, classifying his research periods in two sub-periods (1997-2004 old period and 2005-12 recent period). Herding was found to be respectably strong in the first period but declined in the second period, indicating a deeper market structure compared to the former period. Furthermore, it is seen that no herding effect has been detected during bearish market structure. Thus, it has been perceived as an opportunity for portfolio diversification on behalf of risk minimization.

Dogukanli and Ergun (2011) examined herding in the ISE for monthly returns during 2000-10 by considering medium- and long-term trends. No existence of the behavior was detected. In a second study, Dogukanli and Ergun (2015) searched for herding by covering 15 different sectors in the BIST between 4.01.2000 and 28.09.2012, considering daily and weekly stock prices. Again, no herding effect was detected.

Considering behavioral finance and organizational behavior perspectives, Ulusan et al. (2013) analyzed the herd behavior effect on ten banking stocks trading in the BIST between 02.01.2008 and 31.12.2012. While no herding was detected, it was emphasized that this result could be an indication of investors with high locus of control and the existence of a weak-form efficient market structure.

Demir et al. (2014) tested emotional herding over 10 years in the BIST and determined that there is a significant and consistent herding, independent of trading volume and stock return. They also found that the local financial crisis of 2000-01 had led to herding in the BIST and that thereafter there had been a quiet market for a period; however, herd behavior was once again detected toward the end of 2011, due to both internal and external developments.

An interesting study was conducted by Solakoğlu et al. (2016). This study involved the impacts of elections and international Central Bank meetings on herding in the BIST. Analyses of the BIST-30 and Second National Market revealed no herding. However, a weak level of significance of herd behavior was observed in the Second National Market in the day following European Central Bank, Bank of England and Bank of Japan meetings, and it was also revealed that investors in both markets perceived the pre-election period as a market stress. Another study regarding herding during election periods in the BIST was carried out by Can Ergun (2018). The findings, covering the 1997-2017 period, indicated no herd behavior in the BIST, with the result interpreted as investors having no tendency to mimic others during election periods.

Durukan et al. (2017) examined herding in the BIST on behalf of foreign investors during the financial crisis. Their findings indicated herding but its affect among foreign investors had declined related to lower trading volumes during the crisis. It was also revealed that small and lower return offering companies were more affected by herd behavior.

Cimen and Can Ergun (2019), as a novelty, tested herding just after the initial public offering (IPO) in BIST between 2007 and 2017. A total of 101 daily returns of the IPO aftermarket during a 30-day period were used, and no herding was detected.

The literature on calendar anomalies can be classified under two main sub-titles, namely Gregorian and Hijri calendar-based anomalies. Gregorian calendar anomalies involve day-of-the-week, week-of-the-month, month-of-the-year, turn-of-themonth, turn-of-the-year effects while the Hijri Calendar taken as a reference by Muslim countries determines effects in the Islamic months (Ramadan, Zul-Hijjah, Muharram etc), on Mavlid (the birth of the Islamic Prophet Mohammed) and on religious holidays (Eid al-Fitr and Eid al-Adha). Turkey, having the majority of Muslim population, uses the Gregorian calendar but in combination with the major Islamic holy days listed above, making it a supplementary task there to research these Hijri calendar effects for anomalies when studying investor behavior.

The first calendar anomaly study was conducted by Fields (1931), although the findings this yielded were not strong enough to clearly validate the anomaly approach. Some four decades later, Cross (1973) analyzed the S\&P Composite Index between 1953 and 1970 and determined that the Monday return was lower and Friday return higher than that of the previous day. Thus, a DoW effect was confirmed. Thaler (1987a, 1987b) and DeBondt and Thaler (1987) made major contributions to the literature when pioneering the behavioral finance approach for the investigation of January, weekend, holiday, turn-of-themonth and intraday effects. 
Among international studies that included Turkey, one by Seif et al. (2017) analyzed January, DoW, holiday and week-of-theyear effects in nine countries' stock exchanges over a period ranging across 20 to 40 years and detected anomalies for each of these other than January in all exchanges. Bozkurt (2015) tested DoW, January, Friday the $13^{\text {th }}$, and full moon effects in 12 developed and developing stock exchanges for 2000-14 by indicating differentiation. The results showed a DoW effect in Brazil, Peru, Poland, UK, and Singapore, a January effect in India and the UK, a full-moon effect in Turkey, Brazil, Poland, Japan, USA, and Canada, and Friday-the- $13^{\text {th }}$ effect in Mexico. No relation was revealed between level of development and anomaly.

Another study was designed by Al-Khazali ve Mirzaei (2017). DoW, week-of-the-month, and January effects were analyzed in eight Dow Jones Islamic Indices for 1996-2015 in five sub-periods using the Adaptive Market Hypothesis (AMH). Seasonal effects were verified over time and supported the $\mathrm{AMH}$. Islamic indices achieved greater efficiency over time, particularly during the recent financial crisis. The AMH offered a better explanation of calendar anomalies than did the Efficient Market Hypothesis (EMH). Monday and Friday effects weakened over time, a weekly effect was detected in all sub-periods, and a January effect was found from mid to weak levels.

Irfan et al. (2017) covered four countries with mainly Muslim population, including Turkey, for 2001-14, examining the effects of the Muharram and Ramadan months, the birth of Prophet Mohammed, and Eid al-Adha. They detected Ramadan effect in all markets, but the other anomalies were not observed. However, a Friday effect, similar to DoW in Gregorian calendar, was also found.

Akhter et al. (2015) considered the analysis of calendar anomalies in the stock markets of six countries with mainly Muslim population through a conversion of Gregorian to Hijri calendar dates and researched a Zul-Hijjah effect on return and trading volumes. In terms of volume-based volatility, a negative Zul-Hijjah effect was encountered in Turkish, Moroccan and Egyptian markets; no Zul-Hijjah effect was seen in Malesia, Pakistan or Indonesia, within the context of volatility. Considering returns, a negative Zul-Hijjah effect was detected in Malesia but not in the other markets. Thus, no Zul-Hijjah effect at all was found in Pakistan, while the effect was detected in terms of return and volatility in Indonesia.

As seen from the international studies, Turkey has been included in both Gregorian- and Hijri-calendar-based researches. In line with this, the national literature has also used both of these classifications when studying calendar effects at home only, in Turkey.

Balaban's study (1995) prompted many others to be interested in the field. While confirming the existence of a DoW effect in the BIST, Balaban found the direction and magnitude of the effect to change over time.

Yigiter et al. (2016) considered the DoW effect on the BIST-100 for the period January 2008 to January 2014. Differentiation was found among days of the week but no significant anomaly located. Cengiz et al. (2017) analyzed 289 companies (sectoral classified) for January 2010 to October 2014 seeking to catch any dependency of Monday returns on other days. A Monday dependency was found, varying by sector and generally negative. Tuesday showed the lowest effect, Thursday and Friday the highest. Hence, a DoW effect was detected in the BIST and a non-efficient market structure highlighted.

Karcioglu and Ozer (2017) conducted a study of calendar anomalies in BIST that examined DoW and holiday effects for 200216, divided in two (crisis and non-crisis) sub-periods to show the impact of 2008 global crisis. Both DoW and holiday effects were detected in the BIST-100 (on returns and volatility) during both periods. Five sectoral indices in the BIST exhibited negative returns on Monday, while all other indices (except BIST Industrial) showed positive returns on Wednesday. Arı and Yuksel (2017), Oncu et al. (2017) and Toraman et al. (2017) all detected a DoW effect in the BIST. Bilir (2018), meanwhile, tested for a January effect on the BIST-100 and four sectoral indices for 2008-16; four of the five indices exhibited the effect.

A rarely studied topic among Gregorian calendar anomalies is the "Other January Effect". Ozkan and Zeytinoglu (2018) conducted research in the BIST to fill the gap on this topic. They analyzed the January positive/negative returns' power of estimation over other months for the period January 1989 to December 2016. No "Other January Effect" was observed in the BIST; however, "Other February and Other August" effects were caught.

The national studies listed below focused on Hijri calendar-based anomalies in Turkey. Kucuksille et al. (2015) covered Ramadan and all Islamic month effects for 1988 to 2014. They found significant differences in terms of returns but no Ramadan effect. The month of Rajab had highest return, Ramadan was fourth, and Rabee Al-Awwal the lowest.

In another study, designed by Tan (2017), the Ramadan effect on the BIST-100 and 23 sectoral indices was analyzed for January 1997 to December 2015. Findings indicated the effect to be significant and positive for just five sectors, with the average returns of some sectors being relatively higher than those of the BIST-100 during the month. Alsu et al. (2018) found a Ramadan effect in BIST on Islamic markets for the daily returns of the Participation-30 Index between 17.02.2011 and 30.12.2016. Their findings revealed that there has been a decline in the second 10 days of Ramadan, due to investors' 
devoting themselves to religious rituals. However, the last 10 days of the month exhibited an upward trend related with the preparation for Eid al-Fitr. On the other hand, Ozkan and Akbalik (2018) found no Ramadan effect for 22 stocks between March 2003 and October 2015. However, they did encounter some other Islamic month effects AKENR and KIPA company stock returns, both in positive and negative directions (respectively, for the months of Rabi' al-thani and Rajab and for Rabee Al-Awwal and Jumada al-Awwal).

A further study, covering the Ramadan effect on return and volatility in countries with mainly Muslim population, including Turkey, was carried out by Gunes (2018). Here, the Participation-30 Index of Turkey, Dow Jones (DJ) Islamic Market World Index, MSCI ACWI Islamic Index, S\&P Global BMI Sharia Index, Tadawul (Saudi Arabia) and JKSE (Indonesia) indices were analyzed for May 2013 to January 2018, by considering daily prices. No Ramadan effect on returns of Islamic indices was encountered, although there was an increase then in the volatility of return on DJ and MSCI Indices.

A study on the BIST-100 including both Gregorian and Hijri calendar-based effects was designed by Ulusan Polat et al. (2019). This revealed January and Turn-of-the-Month effects (ToM) effects during December 2006 - December 2017 on volatility, when considering trading volume. Furthermore, volatility was shown to decline in bullish markets. Such a determination under asymmetric volatility partially supports the study's evidence of no anomaly detection in forecasting the BIST-100 index.

In the last stage of literature review, works that have investigated both herding and calendar anomalies are listed.

Gavriilidis et al. (2016) focused on investment psychology, herding, and Ramadan effects in seven countries with mainly Muslim population. The findings indicated that investors with positive moods exhibit significant and intensive herding during Ramadan, as compared to other months. However, the levels among countries varied. A further study analyzed herding in relation to Monday irrationality (as a DoW effect) (Brahmana et al. 2012). This research was carried out on the Malesia Stock Exchange for the period 1990 to 2010 and determined that herding is an indicator of Monday irrationality. Batmunkh et al. (2017) covered Hong-Kong, Japan and Singapore for the period 2000-15 by testing significant herding, inclination to herd behavior, and the Chinese New Year effect on investor behaviors. The results showed significant herding and inclination to herd behavior and an impact of the Chinese New Year on investor behaviors.

It becomes apparent from this comprehensive literature survey that there is a gap in the research regarding Turkish capital market-related combined studies on herding and calendar anomalies. The main aim of this, therefore, is to fill this gap, using analyses of the BIST-100 and sectoral indices. It also serves to underline the fact that behavioral finance should be handled through a wide perspective while developing an investor-focused approach.

\section{DATA AND METHODOLOGY}

This work attempts to verify the theoretical inductions and above-mentioned findings through the application of econometric models. Accordingly, the autoregressive conditionally heteroskedastic (ARCH) family of models has been used for exploring conditional variance due of the assumed effects on the stock market. The ARCH models have been used to investigate the effects of financial volatility (Engle, 1982; Hayo and Kutan, 2005; Wu and Shea 2011), and are often used with high-frequency data. The ARCH models were designed to capture periods of large and volatile movements followed by normal periods, these being generated either endogenously or exogenously. The relationship of stock market anomalies with calendar and herding effects is ideally be tested over relative long-time period with low frequency (Beaumont et al., 2008).

The study is based on the weekly BIST-100 and other major industry and services indices for January 2012 to December 2016. An emphasis on data frequency in empirical analysis is regarded as important. Frequency changes, period differentiations, or even a variety of softwares might lead to different findings in the same area. Here, the first week's data was missed as the returns were calculated. Thus, the data consisted 260 time-points per five working days, making total of 4680 valid observations. This allowed for the study of a DoW effect. Returns have been calculated as suggested by Urquhart and McGroarty (2014). The changes at the volume were calculated accordingly:

$r_{i, t}=\ln I_{i, t}-\ln I_{i, t-1} ; \quad v_{t}=\ln V_{t}-\ln V_{t-1}$

where $\ln l_{i, t}$ is the natural logarithm of the $i^{\text {th }}$ stock exchange index at time point $t$, and $V_{t}$ is total stock market volume on the related day. The sequence plot of daily returns can be seen in Figure 1. 
Figure 1: Sequence Plot of Daily Returns

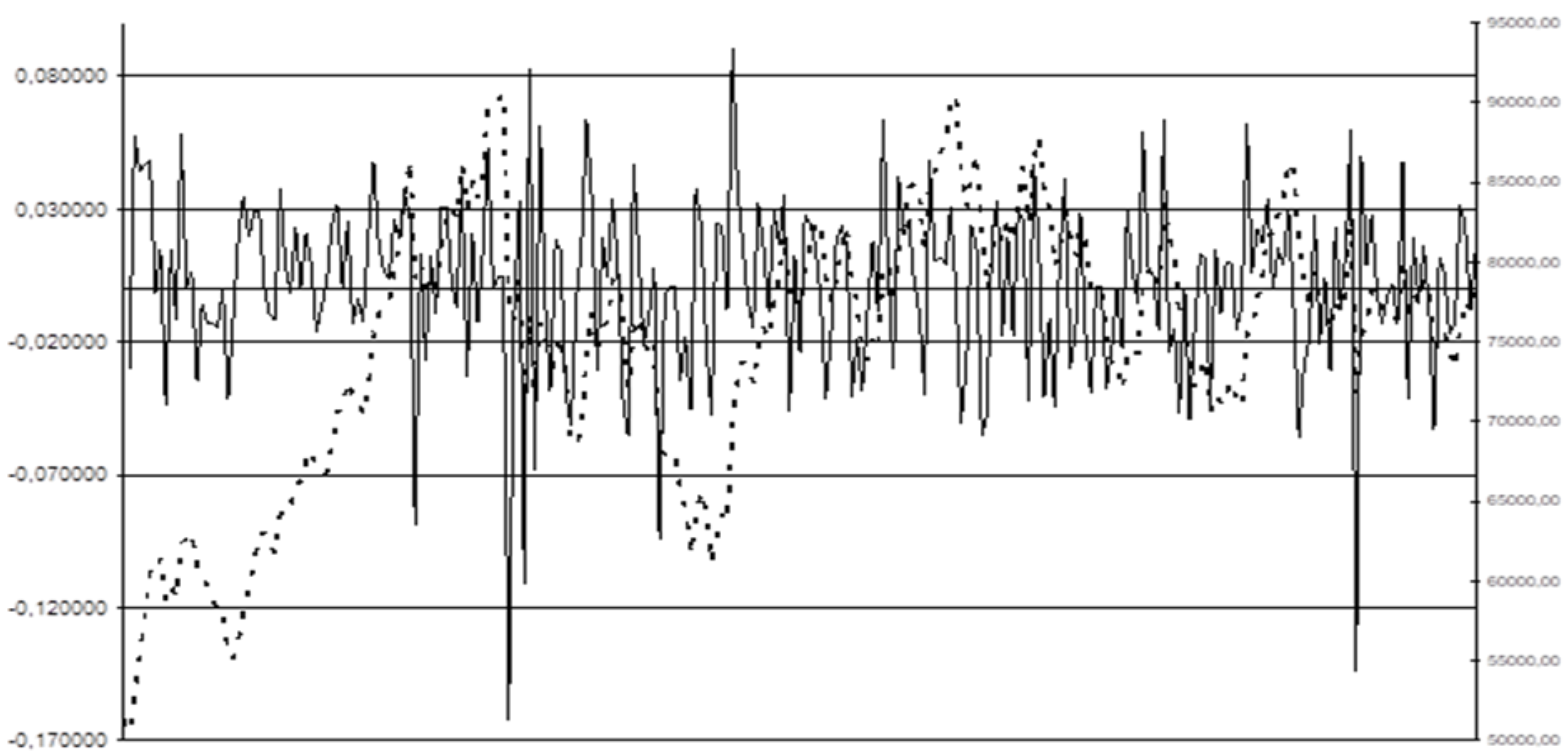

Return-r - - B BIST 100

The number of contracts $\left(C_{t}\right)$ might be another indicator of herding and the change of contract number $c_{t}$ in five days was calculated simply as,

$c_{t}=\frac{C_{t}-C_{t-1}}{C_{t-1}}$

Figure 2, below, indicates the sequence plot of trading volume and the number of traded contracts.

Figure 2: Sequence Plot of Volume and Contracts

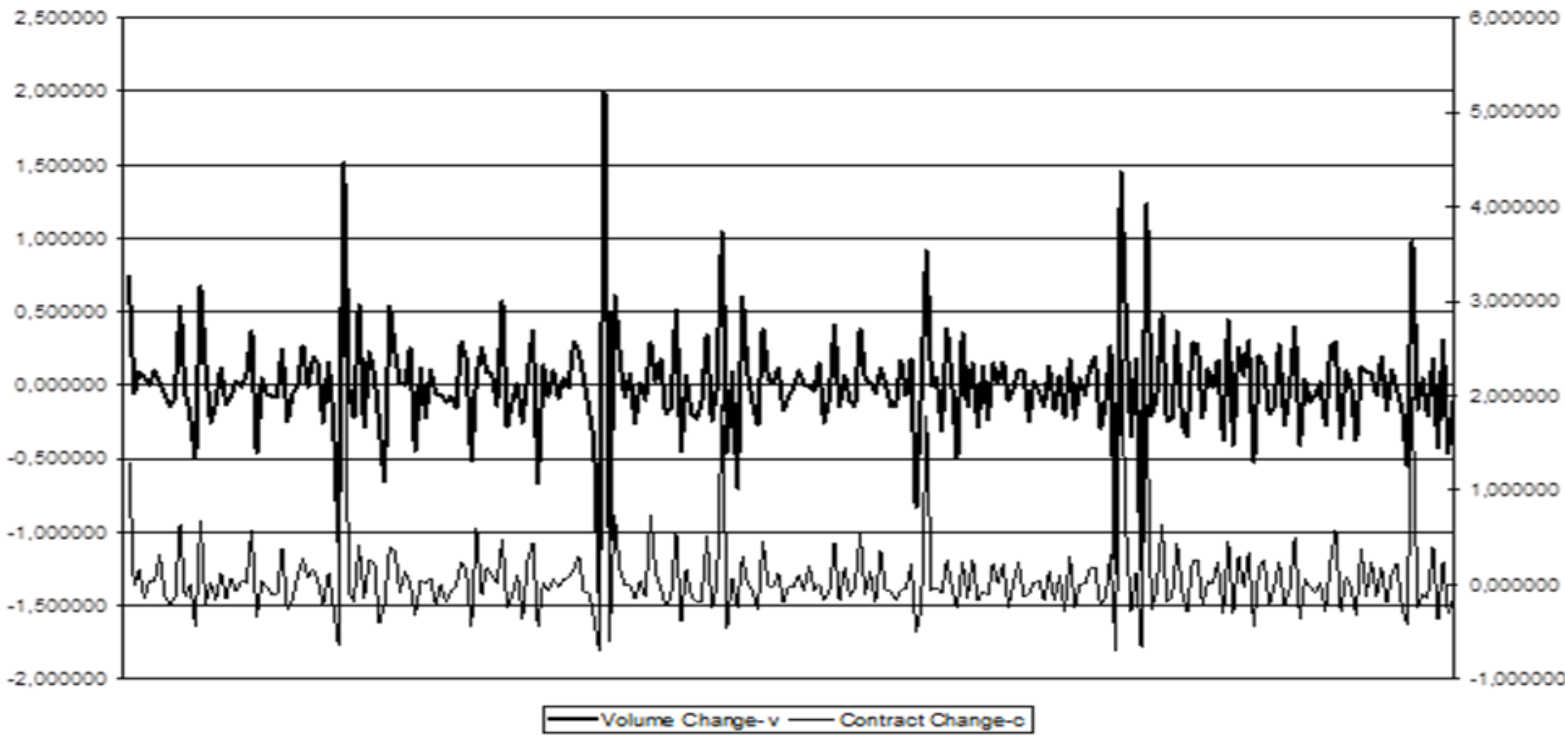


The main descriptive statistics and normality test results are presented in Table 1, with figures given for the BIST100 index, volume and contract number changes. The industry and services sub-indices' statistics had not been statistically analyzed for distributional properties.

\section{Table 1: Descriptive Statistics}

\begin{tabular}{lrrr} 
Statistics & Return (r) & Volume (v) & Contract (c) \\
\hline Lower 5\% percentile & -0.0485 & -0.4996 & -0.4002 \\
\hline Upper 5\% percentile & 0.0491 & 0.5447 & 0.6211 \\
\hline Median & 0.0043 & 0.0024 & -0.0142 \\
\hline Mean & 0.0016 & 0.0032 & 0.0784 \\
\hline Standard Dev. & 0.0333 & 0.3740 & 0.5420 \\
\hline Skewness & -0.9495 & 0.6721 & 4.7505 \\
\hline Kurtosis & 6.2500 & 9.0599 & 35.1605 \\
\hline Shapiro-Wilk normal & $0.9513^{* *}$ & $0.8919^{* *}$ & $0.6016^{* *}$ \\
\hline Shapiro-Francia normal & $0.9477^{* *}$ & $0.8855^{* *}$ & $0.5932^{* *}$ \\
\hline Shapiro-Wilk lognormal & $0.9513^{* *}$ & $0.8919^{* *}$ & $0.6016^{* *}$ \\
\hline Positive changes 5-daily & 147 & 132 & 124 \\
Negative changes 5-daily & 113 & 128 & 136
\end{tabular}

As mean index return, the lower and upper $90 \%$ confidence interval seems to be symmetric, although positive changes for five days are 34 times greater in 260 observations. The logarithmic returns are skewed left, indeed, which means extreme falls at prices than gains. The logarithmic change of volume and percent change of contract number have an asymmetric upper $5 \%$ percentile. The numbers of positive changes in five days are more than negative ones for logarithmic return and logarithmic volume change. None of these variables are distributed either normally or log-normally according to Shapiro tests. The industries and services index returns are also distributed non-normally.

This study assumed that the whole market had to be affected by the herding effect and the calendar dependent anomalies, which were investigated through 15 dummy variables $\left(D_{j}\right)$, nine for calendar and six for herding effects. The collinear dummy variables have been implied as Asteriou and Bashmakova (2013) suggest for determining the mentioned effects. However, the main Istanbul stock market index BIST-100 includes the assets with a relatively lower volatility and of higher scaled companies. Thus, the rule had to be generalized for different industries, trades, and services. The study aimed to investigate the special stock indices simultaneously, leading to the methodology as indicated on panel data, comprising 17 indices. The descriptive statistics can be seen in Table 2 .

\section{Table 2: Descriptive Statistics}

\begin{tabular}{l|r|r|r|r} 
ISE-Indices & Mean $\left(\boldsymbol{r}_{\boldsymbol{i}}\right)$ & Standard Dev. & Skewness & Kurtosis \\
\hline BIST100 & 0.0016 & 0.0333 & -0.9495 & 6.2500 \\
\hline XELKT-Electricity & 0.0007 & 0.0393 & -0.5790 & 5.4304 \\
\hline XGIDA-Food & 0.0005 & 0.0331 & -0.2589 & 4.9751 \\
\hline XUHIZ-Services & 0.0015 & 0.0279 & -0.8306 & 6.3851 \\
\hline XILTM-Communication & -0.0002 & 0.0322 & -0.5292 & 4.9913 \\
\hline XTEKS-Textile & 0.0012 & 0.0315 & -0.5476 & 5.4694 \\
\hline XKAGT-Paper & 0.0025 & 0.0343 & -0.3918 & 6.9338 \\
\hline XKMYA-Chemicals, Oil & 0.0023 & 0.0320 & -0.4372 & 3.8724 \\
\hline XTAST-Stone, Soil & 0.0013 & 0.0293 & -1.0178 & 6.2946 \\
\hline XMANA-Metal (main) & 0.0033 & 0.0382 & -0.4815 & 3.9089 \\
\hline XMESY-Metal Com., Machine & 0.0042 & 0.0326 & -0.8714 & 6.7077 \\
\hline XULAS-Transportation & 0.0068 & 0.0659 & 5.6916 & 69.1387 \\
\hline XTRZM-Tourism & 0.0004 & 0.0372 & -0.8869 & 6.6171 \\
\hline XTCRT-Trade & 0.0023 & 0.0325 & -0.4384 & 4.4559 \\
\hline XUTEK-Technology & 0.0047 & 0.0365 & -1.0436 & 11.1469 \\
\hline XBLSM-Information Tech. & 0.0026 & 0.0403 & 0.0909 & 10.3091 \\
\hline XSPOR-Sport & -0.0003 & 0.0506 & 0.1460 & 6.4560 \\
\hline XUSIN-Industry & 0.0021 & 0.0276 & -0.9005 & 6.2378 \\
\hline & & & &
\end{tabular}


The stock index returns were all left-skewed except for the transportation, sports, and information technologies sectors. The communication and sports sector index returns had negative means return through the 2012-16 period. They all had peak distributional curves, meaning that most observations were deviated about the mean but had extreme values and/or also outliers. Nelson (1991) proposed a generalized error distribution for GARCH model error terms to deal with excess kurtosis instead of normal or t-distributed error terms. Therefore, the generalized error distribution (GED) with $\lambda$ shape coefficient was used in model parameter estimations. The mean and the standard deviations of BIST-100 and other sector indices can be seen in Figure 3.

\section{Figure 3: Mean and Standard Deviations of BIST-100 and Sector Indices}

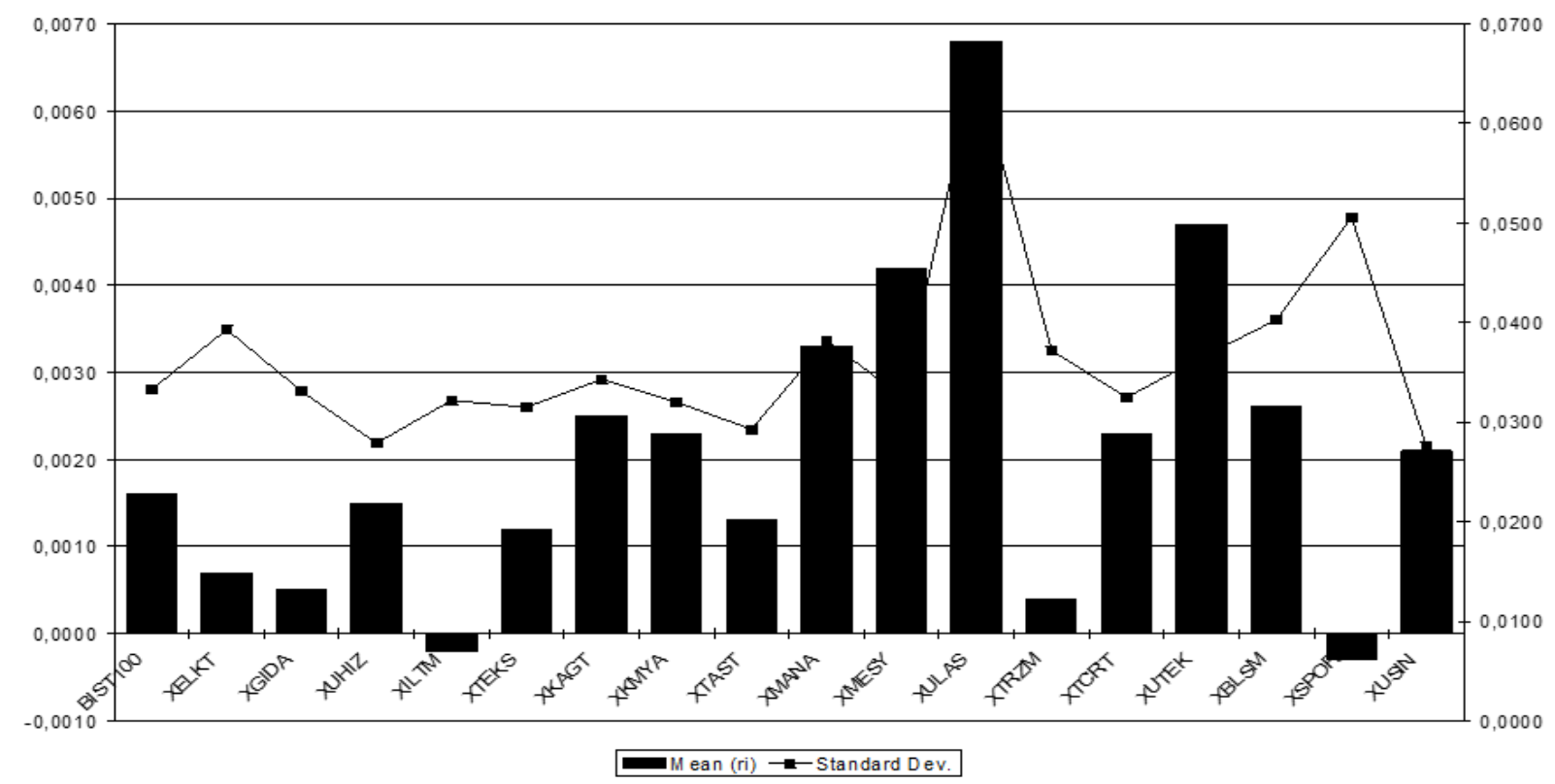

The main problem was in choosing the appropriate estimator from the ARCH models, which depends on the data set. The predictive power of a simple and most robust $\mathrm{GARCH}(1,1)$ model challenges others and it is also an often-used model, when there are effects on the data and related to some additional affecting exploratory variables in modeling (Engle, 2001; Lunde and Hansen, 2005) ); it also dominates other models and $(p, q)$ values, especially for BIST (Çağlayan, 2011; Baklaci and Tütek, 2006). Furthermore, $\operatorname{GARCH}(p, q)$ models allow one to model the variance as conditional on past variance and error, instead of holding it fixed through the series (Engel and Rangel, 2008; Urquhart and McGroarty, 2014). Larger volatilities are to be expected in emerging markets and low growth economies. This is known as a dampening effect on volatility in the presence of robust economic growth. It moderates wildly swinging asset prices and the need to gather together the expectations of traders in response for the next news. Thus, some combination of present and past movement accounted for the time-varying nature of stock returns.

The maximum lag number should be determined for the vector autoregressive component of the model. Generally, an LR test is used to determine the lag period $p$, which compares the VAR model with $p$ lags versus the one with $p$ - 1 lags. The Akaike Information Criterion (AIC) should minimize discrepancy between the given model and the true one (Amemiya, 1985). The similar criteria, SBIC and HQIC, have theoretical advantages over AIC, as demonstrated by Lütkepohl (2005); choosing $p$ with these provides consistent estimates of the true lag order with a positive probability. Lütkepohl versions of information criteria are; 


$$
\begin{aligned}
& A I C=\ln (|\Sigma|)+\frac{2 p M^{2}}{T} \\
& S B I C=\ln (|\Sigma|)+\frac{\ln (T)}{T} p M^{2} \\
& H Q I C=\ln (|\Sigma|)+\frac{2 \ln [\ln (T)]}{T} p M^{2}
\end{aligned}
$$

which reduces the constant term as it does not affect the inference. The FPE formula with any constant term and with the implementation of variable drops because the collinearity is;

$$
F P E=|\Sigma|\left(\frac{T+\bar{m}}{T-\bar{m}}\right)^{M}
$$

The log likelihood for a $\operatorname{VAR}(p)$ is;

$$
L L(l)=-\left(\frac{T}{2}\right)[\ln (|\hat{\Sigma}|)+M \ln (2 \pi)+M] ; l=1,2, \ldots, p
$$

with $\mathrm{M}$ equations. Then, the LR statistics for the lag order / are written as;

$$
L R(l)=2[L L(l)-L L(l-1)]
$$

The error terms of the VAR model satisfy the mean zero and contemporaneous covariance matrix of error terms $\Sigma$ so that there is no serial correlation in individual error terms across time.

\section{FINDINGS AND DISCUSSIONS}

A Hadri LM test was employed to detect the unit root stationary logarithmic changes of the return including time trend. The likelihood ratio of variance was assumed as Parzen's kernel function. Several lags were tried to avoid false estimation. The null hypotheses that all panels are stationary was not rejected. Furthermore, the dependent variable return and explanatory variables were investigated with the Levin-Lin-Chu unit-root test using Bartlett kernel function, where panel means were included but cross-sectional means and time trend were removed. The null hypotheses were all rejected, which indicates that the panel contains unit roots. Bartlett kernel function used 20 lags on average for the LR long term variance, which was chosen by LLC. In Table 3, the average lags are reported for ADF regressions with common AR parameters, where lags were chosen by the Bayesian Information Criterion (BIC).

Table 3: Optimum Lags

\begin{tabular}{lrrrr} 
Lag & Return (trend)) & Return (w/o trend) & Volume (w/o trend) & Contracts (w/o trend) \\
\hline 1 & $-0.2914(0.615)$ & $-0.5327(0.703)$ & $-4.3489(1.000)$ & $-1.7159(0.957)$ \\
\hline 2 & $-0.2186(0.587)$ & $-0.3317(0.630)$ & $-4.1579(1.000)$ & $-1.2408(0.893)$ \\
\hline 3 & $-0.0181(0.507)$ & $-0.2085(0.583)$ & $-3.9428(1.000)$ & $-0.8721(0.808)$ \\
\hline 4 & $0.0878(0.465)$ & $-0.1490(0.559)$ & $-3.7169(0.999)$ & $-0.5711(0.716)$ \\
\hline 5 & $0.1497(0.441)$ & $-0.1191(0.547)$ & $-3.4759(0.999)$ & $-0.3329(0.630)$ \\
\hline Lags & & 0.17 & 0.78 & 0.22 \\
\hline Adj. t & & -80.7695 & -93.8367 & -99.1149 \\
\hline Sig. & & 0.0000 & 0.0000 & 0.0000 \\
\hline
\end{tabular}

The optimum lag was selected for pre-estimation purposes via criteria for vector autoregressive models. The criteria computed in this study sequentially were likelihood ratio tests ( $d f=9$ for each panel), FPE, AIC, HQIC and SBIC for a maximum four lags. The null hypothesis of the LR test was that all the coefficients on the $p^{\text {th }}$ lag of the endogenous variables would be zero, which should be rejected at the maximum level of $p$. The main three variables return, volume change and contract number change assumed endogenous variables with a constant exogenous term. The results have been summarized for each panel in Table 4. 
Table 4: Results of panel data analysis

\begin{tabular}{l|r|r|l|l|l|l|l|l|l|l|r|r} 
Panel & lag & \multicolumn{1}{l|}{ LL } & LR & $\mathbf{p}$ & lag & FPE & lag & \multicolumn{1}{l}{ AIC } & lag & HQIC & lag & \multicolumn{1}{l}{ SBIC } \\
\hline X100 & 3 & 453.6 & 19.04 & 0.025 & 3 & $7.3 \mathrm{e}-6$ & 3 & -11.846 & 2 & -11.742 & 1 & -11.599 \\
\hline XELKT & 3 & -204.4 & 18.13 & 0.034 & 3 & $1.3 \mathrm{e}-3$ & 3 & -6.706 & 2 & -6.605 & 1 & -6.527 \\
\hline XGIDA & 2 & 128.0 & 25.86 & 0.002 & 2 & $8.7 \mathrm{e}-5$ & 2 & -9.373 & 1 & -9.292 & 1 & -9.218 \\
\hline XUHIZ & 3 & 425.0 & 24.59 & 0.003 & 3 & $9.2 \mathrm{e}-6$ & 3 & -11.623 & 1 & -11.537 & 1 & -11.463 \\
\hline XILTM & 3 & 104.4 & 24.87 & 0.003 & 3 & $1.1 \mathrm{e}-4$ & 3 & -9.118 & 2 & -8.991 & 1 & -8.887 \\
\hline XTEKS & 3 & 126.6 & 19.20 & 0.024 & 3 & $9.4 \mathrm{e}-5$ & 3 & -9.292 & 2 & -9.187 & 1 & -9.059 \\
\hline XKAGT & 1 & -133.4 & 53.01 & 0.000 & 1 & $6.3 \mathrm{e}-4$ & 1 & -7.401 & 1 & -7.351 & 1 & -7.277 \\
\hline XKMYA & 3 & 284.7 & 20.87 & 0.013 & 3 & $2.7 \mathrm{e}-5$ & 3 & -10.527 & 1 & -10.435 & 1 & -10.360 \\
\hline XTAST & 4 & 125.2 & 19.30 & 0.023 & 2 & $1.0 \mathrm{e}-4$ & 2 & -9.225 & 1 & -9.160 & 1 & -9.085 \\
\hline XMANA & 4 & 219.2 & 20.47 & 0.015 & 4 & $4.9 \mathrm{e}-5$ & 4 & -9.945 & 1 & -9.851 & 1 & -9.777 \\
\hline XMESY & 2 & 280.5 & 23.78 & 0.005 & 2 & $2.6 \mathrm{e}-5$ & 2 & -10.564 & 1 & -10.492 & 1 & -10.417 \\
\hline XULAS & 4 & 43.9 & 17.45 & 0.042 & 2 & $1.9 \mathrm{e}-4$ & 2 & -8.601 & 1 & -8.507 & 1 & -8.433 \\
\hline XTRZM & 2 & -72.0 & 29.10 & 0.001 & 2 & $4.2 \mathrm{e}-4$ & 2 & -7.810 & 1 & -7.717 & 1 & -7.642 \\
\hline XTCRT & 4 & 157.4 & 25.95 & 0.002 & 4 & $8.0 \mathrm{e}-5$ & 4 & -9.462 & 2 & -9.338 & 1 & -9.258 \\
\hline XUTEK & 3 & 101.2 & 17.40 & 0.043 & 2 & $1.2 \mathrm{e}-4$ & 2 & -9.096 & 1 & -9.029 & 1 & -8.955 \\
\hline XBLSM & 3 & 47.3 & 20.50 & 0.015 & 3 & $1.8 \mathrm{e}-4$ & 3 & -8.672 & 1 & -8.597 & 1 & -8.523 \\
\hline XSPOR & 3 & -354.1 & 21.10 & 0.012 & 3 & $4.0 \mathrm{e}-3$ & 3 & -5.537 & 2 & -5.424 & 1 & -5.338 \\
\hline XUSIN & 3 & 505.6 & 21.16 & 0.012 & 3 & $4.9 \mathrm{e}-6$ & 3 & -12.252 & 1 & -12.147 & 1 & -12.073
\end{tabular}

Note: LL: Log Likelihood; LR: Likelihood Rate Test Statistics; FPE: Final Prediction-Error Criteria; AIC: Akaike Information Criteria; SBIC: Schwarz Information Criteria; HQIC: Hannan-Quinn Information Criteria.

Accordingly, four lags is the maximum lag number of the VAR model assuming all variables were endogenous. They all had to have the same order of integration except when they were all non- stationary. The model of the study investigated the returns. Then, the VAR model was evaluated, with the return as endogenous; volume and contract number changes were exogenous with the constant term. Thus, the lag determination statistics for each panel were studied for vector error correction lag determination statistics with maximum 36 lags. The results are given in Table 5.

Table 5: VAR and VEC Model statistics

\begin{tabular}{|c|c|c|c|c|c|c|c|c|c|c|c|c|c|c|}
\hline & VAR & tatistics & & & & & & VEC & Mean Sta & istics & & & & \\
\hline Panel & lag & LR & Sig. & lag & HQIC & lag & SBIC & lag & LR & Sig. & lag & HQIC & lag & SBIC \\
\hline $\mathrm{X} 100$ & 14 & 3.967 & 0.046 & 1 & -3.93 & 0 & -3.90 & 34 & 4.103 & 0.043 & 1 & -6.77 & 0 & $\begin{array}{r}- \\
6.76 \\
\end{array}$ \\
\hline XELKT & 14 & 5.301 & 0.021 & 0 & -3.76 & 0 & -3.73 & 14 & 5.151 & 0.023 & 0 & -6.59 & 0 & $\begin{array}{r}- \\
6.59\end{array}$ \\
\hline XGIDA & 9 & 4.803 & 0.028 & 1 & -3.93 & 1 & -3.89 & 35 & 4.345 & 0.037 & 1 & -6.78 & 1 & $\begin{array}{r}- \\
6.77 \\
\end{array}$ \\
\hline XUHIZ & 15 & 6.808 & 0.009 & 0 & -4.27 & 0 & -4.24 & 15 & 6.844 & 0.009 & 0 & -7.11 & 0 & $\begin{array}{r}-11 \\
\end{array}$ \\
\hline XILTM & 15 & 12.152 & 0.000 & 0 & -3.96 & 0 & -3.94 & 15 & 10.576 & 0.001 & 0 & -6.81 & 0 & $\begin{array}{r}- \\
6.81\end{array}$ \\
\hline XTEKS & & & & 0 & -4.11 & 0 & -4.08 & & & & 0 & -6.95 & 0 & $\begin{array}{r}- \\
6.95 \\
\end{array}$ \\
\hline XKAGT & 1 & 4.755 & 0.029 & 1 & -4.11 & 0 & -4.08 & 1 & 5.192 & 0.023 & 1 & -6.96 & 0 & $\begin{array}{r}- \\
6.95 \\
\end{array}$ \\
\hline XKMYA & 1 & 5.022 & 0.025 & 2 & -4.16 & 0 & -4.12 & 33 & 7.013 & 0.008 & 1 & -7.01 & 0 & $\begin{array}{r}- \\
7.00\end{array}$ \\
\hline XTAST & 14 & 6.446 & 0.011 & 0 & -4.25 & 0 & -4.23 & 33 & 4.349 & 0.037 & 0 & -7.08 & 0 & $\begin{array}{r}- \\
7.08\end{array}$ \\
\hline XMANA & 10 & 7.882 & 0.005 & 0 & -3.68 & 0 & -3.65 & 36 & 5.657 & 0.017 & 0 & -6.51 & 0 & $\begin{array}{r}- \\
6.51\end{array}$ \\
\hline XMESY & 15 & 4.061 & 0.044 & 0 & -3.97 & 0 & -3.95 & 12 & 4.420 & 0.035 & 0 & -6.80 & 0 & - \\
\hline
\end{tabular}




\begin{tabular}{|c|c|c|c|c|c|c|c|c|c|c|c|c|c|c|}
\hline XULAS & 20 & 6.500 & 0.011 & 0 & -2.53 & 0 & -2.51 & 20 & 5.207 & 0.022 & 0 & -5.37 & 0 & $\begin{array}{r}- \\
5.37\end{array}$ \\
\hline XTRZM & & & & 0 & -3.89 & 0 & -3.87 & 23 & 4.103 & 0.043 & 0 & -6.75 & 0 & $6.75^{-}$ \\
\hline XTCRT & 1 & 7.013 & 0.008 & 1 & -3.99 & 1 & -3.96 & 3 & 3.945 & 0.047 & 3 & -6.88 & 0 & $\begin{array}{r}- \\
6.87\end{array}$ \\
\hline XUTEK & 12 & 4.770 & 0.029 & 0 & -3.86 & 0 & -3.83 & 26 & 5.628 & 0.018 & 0 & -6.73 & 0 & $\begin{array}{r}- \\
6.73\end{array}$ \\
\hline XBLSM & & & & 0 & -3.84 & 0 & -3.81 & 26 & 4.585 & 0.032 & 0 & -6.76 & 0 & $\begin{array}{r}- \\
6.76 \\
\end{array}$ \\
\hline XSPOR & & & & 0 & -3.51 & 0 & -3.49 & 14 & 4.045 & 0.044 & 0 & -6.35 & 0 & $\begin{array}{r}- \\
6.35 \\
\end{array}$ \\
\hline XUSIN & 14 & 6.002 & 0.014 & 1 & -4.33 & 0 & -4.30 & 26 & 4.567 & 0.033 & 1 & -7.16 & 0 & $\begin{array}{r}- \\
7.16\end{array}$ \\
\hline
\end{tabular}

Note: LL: Log Likelihood; LR: Likelihood Rate Test Statistics; FPE: Final Prediction-Error Criteria; AIC: Akaike Information Criteria; SBIC: Schwarz Information Criteria; HQIC: Hannan-Quinn Information Criteria.

The priming variance values were specified by the error terms of the expected unconditional variance of the model from the mean equation and any ARMA terms.

$\sigma_{i, t, 0}^{2}=\frac{\sum_{t=1}^{T} \hat{\varepsilon}_{i, t}^{2}}{T}$

The standard errors were optimized by OPG optimization technique. The $\operatorname{GARCH}(1,1)$ model was tested as several $\operatorname{GARCH}(p, q)$ models did not converge by optimization for $p=1,2,3$ and $q=1,2,3$ combinations except $p=1$ and $q=1$. Also, the VAR model preestimation suggested a maximum three lags for ARCH in means, and VEC statistics suggested a maximum one lag for error terms. Model comparison information criteria HQIC and SBIC supported this decision. The symmetric and asymmetric GARCH models were estimated separately, which allowed for comparison of the nature of volatility of trading by short-term bullish and bearish trends. Any constraints were assumed by the estimation process, with the stationary to be achieved when the sum of the $\alpha_{1}+\alpha_{2}<1$ restriction was satisfied.

$r_{i, t}=\beta_{0}+\beta_{1} v_{i, t}+\beta_{2} c_{i, t}+\sum_{j=3}^{17} \beta_{j} D_{i, t, j}+\sum_{h=0}^{3} \psi_{h} g\left(\sigma_{i, t-h}^{2}\right)+\phi r_{i, t-1}+\theta \varepsilon_{i, t-1}+\varepsilon_{i, t}$

$\operatorname{Var}\left(\varepsilon_{i, t}\right)=\sigma_{t}^{2}=\alpha_{0}+\alpha_{1} \varepsilon_{i, t-1}^{2}+\alpha_{2} \sigma_{t-1}^{2}$

Some studies suggest EGARCH or APARCH model estimations for estimation asymmetric error term leverages, assuming that good and bad news have different effects on the financial spot markets. This study first investigated with the Simple Asymmetric ARCH (SAARCH) model estimation in order to test the effects that down and up movements had different on effect magnitudes in the market. The empirical model was written as the following equations. The return model $r_{i, t}$ with ARCH-in-mean and ARMA terms was the same as the GARCH estimation.

$\operatorname{Var}\left(\varepsilon_{i, t}\right)=\sigma_{t}^{2}=\alpha_{0}+\alpha_{1} \varepsilon_{i, t-1}^{2}+\alpha_{3} \varepsilon_{i, t-1}$

(9)

The Wald test results supported the persistence of the conditional volatility models. The parameter estimations and model fit and significance statistics are presented in Table 6.

Table 6: Wald Test Results for GARCH and SAARCH Models

\begin{tabular}{l|l|l|l|l|l|l} 
& GARCH & & & SAARCH & & \\
\hline & II(model) & AIC & BIC & II(model) & AIC & BIC \\
\hline & 11372,1 & -22688.1 & -22507.36 & 11355,7 & -22655.35 & -22474.72 \\
\hline Wald $\chi^{2}$ & 227892 & $(0.0000)$ & Df $=23$ & 1820000 & $(0.0000)$ & Df=23
\end{tabular}




\begin{tabular}{|c|c|c|c|c|c|c|}
\hline Variable & Coef. & $S_{e}$ & z-Sig. & Coef. & $\mathrm{S}_{\mathrm{e}}$ & z-Sig. \\
\hline$\beta_{1}:$ Vol. $v_{\text {it }}$ & 0.0043 & $6.85 \mathrm{e}-4$ & 0.000 & 0.0041 & $6.82 \mathrm{e}-4$ & 0.000 \\
\hline$\beta_{2}$ :Cont. $c_{i t}$ & 0.0012 & $2.65 e-4$ & 0.000 & 0.0013 & $2.62 \mathrm{e}-4$ & 0.000 \\
\hline$\beta_{3}:$ Post-Holiday & -0.0042 & $6.31 \mathrm{e}-4$ & 0.000 & -0.0043 & $6.33 e-4$ & 0.000 \\
\hline$\beta_{4}:$ Ramadan & 0.0016 & $8.04 e-4$ & 0.047 & 0.0016 & $7.80 e-4$ & 0.045 \\
\hline$\beta_{5}:$ DOW1 & 0.0098 & $7.97 e-3$ & 0.218 & 0.1084 & $8.55 e-3$ & 0.000 \\
\hline$\beta_{6}: D O W 2$ & 0.0080 & $8.01 \mathrm{e}-3$ & 0.316 & 0.1067 & $8.59 e-3$ & 0.000 \\
\hline$\beta_{7}:$ DOW3 & 0.0094 & $7.98 \mathrm{e}-3$ & 0.239 & 0.1082 & $8.55 e-3$ & 0.000 \\
\hline$\beta_{8}:$ DOW4 & 0.0092 & $8.04 \mathrm{e}-3$ & 0.252 & 0.1081 & $8.57 e-3$ & 0.000 \\
\hline$\beta_{9}: D O W 5$ & 0.0121 & $7.99 e-3$ & 0.129 & 0.1109 & $8.56 \mathrm{e}-3$ & 0.000 \\
\hline$\beta_{10}$ :DJan. & 0.0023 & $7.86 \mathrm{e}-4$ & 0.004 & 0.0026 & $7.59 \mathrm{e}-4$ & 0.001 \\
\hline$\beta_{11}:$ DDec. & -0.0018 & $7.39 \mathrm{e}-4$ & 0.015 & -0.0010 & $7.46 \mathrm{e}-4$ & 0.174 \\
\hline$\beta_{12}:$ Drdown & 0.3885 & 0.01068 & 0.000 & 1.7867 & $8.78 \mathrm{e}-3$ & 0.000 \\
\hline$\beta_{13}:$ Drup & 0.4246 & 0.01070 & 0.000 & 1.8230 & $8.79 \mathrm{e}-3$ & 0.000 \\
\hline$\beta_{14}:$ Dvdown & -1.4245 & 0.03212 & 0.000 & 2.4482 & 0.01013 & 0.000 \\
\hline$\beta_{15}:$ Dvup & -1.4251 & 0.03217 & 0.000 & 2.4479 & 0.01011 & 0.000 \\
\hline$\beta_{16}$ :Dcdown & 3.7599 & 0.01266 & 0.000 & 0.3976 & $5.76 \mathrm{e}-3$ & 0.000 \\
\hline$\beta_{17}:$ Dcup & 3.7601 & 0.01264 & 0.000 & 0.3982 & $5.73 e-3$ & 0.000 \\
\hline$\beta_{0}:$ Const. & -2.7513 & 0.03140 & 0.000 & -4.7624 & $6.86 \mathrm{e}-3$ & 0.000 \\
\hline$\Psi_{0}: \mathrm{ARCHM}$ & 11.3586 & 3.67444 & 0.002 & 5.8144 & 1.52904 & 0.000 \\
\hline$\Psi_{1}: \mathrm{ARCHM}$ & -8.4546 & 4.61244 & 0.067 & 1.2333 & 0.75689 & 0.103 \\
\hline$\Psi_{2}: \mathrm{ARCHM}$ & -3.4469 & 4.09794 & 0.400 & -3.2684 & 0.90544 & 0.000 \\
\hline$\Psi_{3}: \mathrm{ARCHM}$ & 2.3038 & 2.80553 & 0.412 & 3.7593 & 0.88351 & 0.000 \\
\hline$\varphi: A R(1)$ & -0.2575 & 0.30925 & 0.405 & -0.2026 & 0.20094 & 0.313 \\
\hline$\theta: M A(1)$ & 0.2290 & 0.31186 & 0.463 & 0.1584 & 0.20503 & 0.440 \\
\hline$\alpha_{0}$ :Const. & 0.00004 & $8.03 e-6$ & 0.000 & 0.0005 & $1.72 \mathrm{e}-5$ & 0.000 \\
\hline$\alpha_{1}: \mathrm{ARCH}(1)$ & 0.0368 & 0.00713 & 0.000 & 0.1351 & 0.02704 & 0.000 \\
\hline$\alpha_{2}: \operatorname{GARCH}(1)$ & 0.8944 & 0.01856 & 0.000 & & & \\
\hline$\alpha_{3}: \operatorname{SAARCH}(1)$ & & & & 0.0001 & $9.43 e-4$ & 0.905 \\
\hline $\ln (\lambda): G E D$ & -0.1079 & 0.01515 & 0.000 & -0.1178 & 0.01323 & 0.000 \\
\hline$\lambda: G E D$ & 0.8977 & 0.01360 & & 0.8889 & 0.01176 & \\
\hline
\end{tabular}

Note: AIC: Akaike Information Criteria; BIC: Bayesian Information Criteria.

The GARCH $(1,1)$ model had a relative greater goodness-of-fit according to AIC and BIC criteria than the SAARCH $(1,1)$ model, and the SAARCH(1) coefficient $\alpha_{3}$ on conditional volatility was insignificant. As the two models had the same number of parameter estimations, the penalty of over-fitting the model for these two statistics did not play a role. As the study used the dummy variables for herding- and date- oriented positive and negative shocks in the mean model, a symmetric error distribution was expected. The estimated values of $\psi_{k}(k \neq 0)$ in the GARCH model are insignificant at $5 \%$ of the significance level, but the first lag of variance's coefficient is significant at the $10 \%$ level, indicating low evidence for a contemporaneous linkage effect between volatility and stock prices change. The negative coefficient (-8.45) indicates that the decreasing volatility was consistent with the higher price increases. However, these coefficients are significant with two and three weeks lagged linkage effect with asymmetric error term effects in the $\operatorname{SAARCH}(1,1)$ model. The positive linkage $\left(\psi_{2}=0.91\right.$ and $\left.\psi_{3}=0.88\right)$ implies slow long-run price change during low volatile market trends. These positive coefficients also confirm the importance of the asymmetry in the return volatility. The insignificant coefficients $\phi$ of $A R(1)$ and $\theta$ of MA(1) estimates reveal that the previous period return and error term had no effect on the conditional return mean in both models. The fact that the sum $\alpha_{1}+\alpha_{2}$ is fairly close to 1 indicates the persistence of past volatilities in explaining current volatility. The shocks on the conditional variance are followed by a post-shock of approximately $94 \%$ in magnitude. The long-run volatility effect $\alpha_{2}$ on return changes is much more than is the short-run return change effect $\alpha_{1}$. It is as low as $14 \%$ in the SAARCH model.

Table 7: The Conditional Means for ARCHM/GARCH and ARCHM/SAARCH Models

\begin{tabular}{l|r|r|r|r|r|r} 
& \multicolumn{2}{|c|}{ ARCHM/GARCH } & \multicolumn{2}{c|}{ ARCHM/SAARCH } & & \\
\hline Variable & Mean & Std.Dev. & Mean & Std.Dev. & Minimum & Maximum \\
\hline Panel $r_{i t}$ & 0.00208 & 0.0374 & $9.872 \mathrm{e}-4$ & 0.0389 & -0.23685 & 0.76592 \\
\hline Panel $v_{i t}$ & 0.00371 & 0.5875 & $1.994 \mathrm{e}-3$ & 0.5949 & -2.90119 & 3.44024 \\
\hline Panel $c_{i t}$ & 0.23603 & 1.1960 & 0.23935 & 1.1585 & -0.93688 & 23.25100
\end{tabular}


The conditional means are given, above, in Table 7. The coefficients of the conditional mean model are significant except for the DOW effects. There is a down effect in December of about $0.2 \%$ and after holidays of $0.4 \%$. The mean returns increase approximately $0.2 \%$ in Ramadan and in January. On the other hand, the increasing returns have a naïve greater effect of about $0.4 \%$ on return changes over decreasing returns in the same direction. However, the volume has a negative effect on returns of about $142.5 \%$, as volume increase with falling returns, which supports the rational trader assumption of Dow Theory and overpricing response at the end of a bullish trend, caused by the herding effect. The same rational is valid for decreasing volumes. The changes in the number of contracts affect the returns much more than others in the same direction.

\section{CONCLUSION}

The study has analyzed Borsa Istanbul herding and calendar anomalies during the period January 2012 to December 2016 by considering weekly data of the BIST-100 index and BIST sectoral indices. During this period, three local-based events, incorporating political and social dimensions, had an impact on Turkish economy. These were the Gezi Park Protests (May 2013), political turmoil (December 2013), and a coup attempt (15 July, 2016). These incidents, however, had no permanent effect leading to long-term-based crisis on either the Turkish economy or Borsa Istanbul.

First, the distributions of the BIST-100 Index and 17 sectoral Indices were analyzed. The findings indicate that falls of prices in the BIST are much more severe than rises. It is also shown that there has been a dominant tendency in upward trend in terms of returns and trading volumes, while the trend is downward for number of contracts, when considering five-daychanges. These findings could be associated with "loss aversion" in the context of behavioral finance. It may be that individual investors, in particular, have avoided taking risk and therefore followed a short-tem-based strategy of realizing gains. Hence, there was a decline in number of contracts. By including corporate investors in this trend also, return- and volume-focused movement, triggering speculative market structure, is observed. Such a construction, in general, confirms the occurrence of speculative trading in the BIST.

On the sectoral basis, there is a distribution around the mean, but also the existence of some excess values indicative of herding. Considering the period, there was a volatile structure in the transport, information technologies and sports indices. A decline in oil prices during the time period, along with the impacts of foreign actors in the market, cargo transportation, digitalization, and government subsidies could all be the underlying reasons for these sectors' speculative returns and make it worth analyzing herd behavior in the BIST.

Following these initial determinations, the existence of herding and calendar anomalies in the BIST, in line with the main hypotheses of the research, have been questioned by considering both the BIST-100 and all sectoral indices, as a whole. Therefore, the estimation models GARCH $(1,1)$, a symmetric ARCH family model, and SAARCH $(1,1)$, an asymmetric model to represent volatility of returns, have been employed for a comparative analysis. It has thus been possible to detect the effects of downward and upward market movements with different magnitudes.

From the findings of the GARCH $(1,1)$ model, purged from volatility affect, an inverse relationship between volume and volatility is observed. In line with this model, comprehending negative and positive shocks together, the simultaneous interaction between volatility and return is quiet weak, and therefore it is not possible to talk about a strong herd behavior in the BIST. At this point, the research was deepened through employment of the SAARCH $(1,1)$ asymmetric estimation model, which revealed an increase in both trading volume and return when considering negative shocks. Hence, a significant herding in BIST has been confirmed. Such a finding can be evaluated as expected, in particular for individual investors, by considering asymmetric information dissemination, the level of financial literacy, and the cost of information. Also, herding may be perceived as an indicator of an efficient market structure where past movements do not obviously explain recent market trends.

A further hypothesis of the study involved an analysis of BIST calendar anomalies. From this perspective, the SAARCH $(1,1)$ model has detected a DoW effect. On Friday, as the last day of the week, there is a significant increase in returns compared to other days, while on Tuesdays, returns are comparatively weak. This finding could be explained by a bullish market trend due to weekend profit- taking and an increase in trading volumes upon return, with bearish market trends in line with the use of buying opportunities at the beginning of the week. Considering the post-holiday effect in the context of religious, national, and official holidays, both symmetric and asymmetric models have encountered a significant effect with a downward trend. This data could be perceived as an indicator of a liquidity requirement of investors as the comebacks from relatively long holidays, where markets are officially closed and investors are unengaged in their business lives. In this context, profit-taking could lead to selling pressure and a downward trend in the market.

A significant January effect has been detected in the BIST when purged from asymmetric effects. As the first month of the year, re-purchases following the closed-out positions in December and "opening a clean page" rituals supported by purchases could be the underlying reasons. 
Regarding Islamic calendar effects, both models have detected Ramadan effect, in line with the academic literature. Even though Ramadan occurred during the summer months in the period studied, the average returns exhibited an upward trend, confirming investors' strong interest in the BIST. It should be emphasized that foreign corporate investors in particular have contributed to this trend during the Ramadan period.

It is important to analyze these findings and take required measures by capital market actors and legislators, in order to achieve to an efficient capital market structure and a rational investor profile. These outputs, giving priority to investor behaviors, could be the milestones of fairer information dissemination among investors and more stable market structures.

In order to shed more light on this subject through further studies, herding and calendar anomalies could be handled separately for all sub-sectors. Analysis of "Other January Effect" for BIST is also required. Finally, the simultaneous existence of both herd behavior and calendar anomalies are worth investigating in the context of Turkish capital markets to increase efficiency.

\section{REFERENCES}

Akhter, A., Sandhu, A., Butt, S. (2015). Islamic Calendar Effect on Market Risk and Return Evidence from Islamic Countries. Journal of Business \& Financial Affairs, 4(2), 1-5.

Al-Khazali, O. M., Mirzaei, A. (2017). The impact of oil price movements on bank non-performing loans: Global evidence from oil-exporting countries. Emerging Markets Review, 31(C), 193-208.

Altay, E. (2008). Sermaye Piyasalarında Suru Davranisi: IMKB'de Piyasa Yonunde Suru Davranisinin Analizi. BDDK Bankacılık ve Finansal Piyasalar, 2(1), 27-58.

Alsu, E., Tasdemir, A., Özyurt, H.K. (2018). Türkiye İslami Piyasalarında Ramazan Ayı Etkisi. Anemon Muş Alparslan Üniversitesi Sosyal Bilimler Dergisi 2018 6(5) 707-712.

Amemiya, T. (1985). Advanced Econometrics. Cambridge, MA: Harvard University Press.

Ari, A., Yuksel, O. (2017). BIST 100’de Haftanin Gunu Anomalisi: Ekonometrik Bir Analiz. Finans Politik \& Ekonomik Yorumlar, 54(632), 77-89.

Asteriou, D., Bashmakova, Y. (2013). Assessing the impact of oil returns on emerging stock markets: A panel data approach for ten Central and Eastern European Countries. Energy Economics, 38, 204-211.

Baklaci, H., Tutek, H. (2006). The Impact of the Futures Market on Spot Volatility: An Analysis in Turkish Derivatives Markets'. Computational Finance and Its Applications II, edited by M. Constantino and C.A.

Balaban, E. (1995). Day of the week effects: new evidence from an emerging stock market. Applied Economics Letters, 2(5), $139-143$.

Batmunkh, M.U.J, Moslehpour, M., Shieh-Liang, C. (2017). Herding Behavior in Advanced Confucian Markets. World Affairs (2) 34(502), 1-26.

Beaumont, P. M., Norrbin, S. C., Yiğit, F. P. (2008). Time series evidence on the linkage between the volatility and growth of output. Applied Economic Letters, 15, 45-48.

BenSaida, A., Jlassi, M., Litimi, H. (2015). Volume-herding interaction in the American market. American Journal of Finance and Accounting, 4(1), 50-69.

Bilir, H. (2018), Ocak Ayı Etkisinin Turk Sermaye Piyasalarında Farklı BIST Endekslerine Gore Analizi. Sosyoekonomi, 26, 145-160.

Blasco, N., Corredor, P., Ferreruela, S. (2012) Does herding affect volatility? Implications for the Spanish stock market. Quantitative Finance, 12(2), 311-327.

Boyd, N., Buyuksahin, B., Haigh, M., Harris, J. (2016). The Prevalence, Sources, and Effects of Herding. The Journal of Futures Markets, 36(7), 671-694.

Bozkurt, I. (2015). Gelismis ve Gelismekte Olan Piyasalarda Anomali Varliginin Incelenmesi. Business and Economics Research Journal, 6(4), 19-37.

Brahmana, R., Hooy, C.W., Ahmad, Z. (2012). Asian Academy of Management. Journal of Accounting and Finance, 8(2), 1-20.

Brebbia, Southampton, UK: WIT Press, 237-246.

Can Ergun (2018), The Effect of Herd Behavior on Stock Markets during the Election Times: Evidence from Borsa Istanbul, Würzburg International Business Forum International Business Conference Proceedings, 97-103.

Cengiz, H., Bilen, O., Buyuklu, A. H., Damgaci, G. (2017). Stock market anomalies: the day of the week effects, evidence from Borsa Istanbul. Journal of Global Entrepreneurship Research, 7(1), 1-11.

Chang, E., Cheng, J. and A. Khorana. (2000). An examination of herd behavior in equity markets: an international perspective. Journal of Banking and Finance, 24(10), 1651-1679. 
Chiang, T.,C., Jiandong, L., Tan, L., Nelling, E. (2011). Dynamic herding behavior in PacificBasin markets: Evidence and Implications, Social Science Research Network (SSRN), Retrieved from http://www.cass.city.ac.uk/ data/assets/pdf file/0006/86622/Chiang.pdf

Cross, F. (1973). The Behavior of Stock Prices on Fridays and Mondays. Financial Analysts Journal, 29(6), 67-69.

Caglayan, E. (2011). The Impact of Stock Index Futures. Journal of Emerging Market Finance, 10(1), 73-91.

Çakan, E., Demirer, R., Gupta, Marfatia, H. (2019). Journal of Economics and Finance, 43(1), 44-56.

Cimen, A., Can Ergun, Z. (2019). Turk Ilk Halka Arz Piyasasinda Suru Davranisinin Ampirik Analizi. Izmir Iktisat Dergisi, 34(1), 67-75.

De Bondt, W. F. M., Thaler, R. (1987). Further Evidence on Investor Overreaction and Stock Market Seasonality. The Journal of Finance, 42(3), 557-581.

Demir, N., Mahmud, S. F., Solakoglu, M. N. (2014). Sentiment and Beta Herding in the Borsa Istanbul (BIST), Contemporary Studies in Economic and Financial Analysis, in Risk Management Post Financial Crisis: A Period of Monetary Easing, 96, Emerald Group Publishing Limited, $389-400$.

Dogukanli, H., Ergun, B. (2011). IMKB'de Suru Davranisi: Yatay Kesit Degiskenlik Temelinde Bir Arastirma. Cukurova Universitesi Isletme Fakultesi Dergisi, 12(2), 227-242.

Durukan, M. B., Ozsu, H. H., Can Ergun, Z. (2017). Chapter 12 - Financial Crisis and Herd Behavior: Evidence from the Borsa Istanbul, in (ed.) Economou, F., Gavriilidis, K., Gregoriou, G. N., Kallinterakis, V., Handbook of Investors' Behavior During Financial Crises, Academic Press, 203217.

Engle, R. F. (1982). Autoregressive Conditional Heteroskedasticity with Estimates of the Variance of U.K. Inflation. Econometrica, 50(4), 9871008.

Engle, R. F. (2001). GARCH 101: The use of ARCH/GARCH models in applied econometrics. Journal of Economic Perspectives, 15(4), 157-168.

Engle, R. F., Rangel, J. G. (2008). The Spline-GARCH Model for Low-Frequency Volatility and Its Global Macroeconomic Causes. Review of Financial Studies, 21(3), 1187-1222.

Ergün, B., Doğukanlı, H. (2015). Hisse Senedi Piyasalarında Sürü Davranışı: BisT’te Bir Araştırma. Journal of International Social Research, 8(40), 690-699.

Fama, E. F. (1970). Efficient Capital Markets: A review of Theory and Empirical Work. Journal of Finance,25(2), 383 - 417.

Fields, M. J. (1931). Stock Prices: A Problem in Verification. The Journal of Business, 4, 415.

Gavriilidis, K., Kallinterakis, V., Tsalavoutas, I. (2016). Journal of Economic Behavior\&Organization, 132, 23-38.

Gunes, H. (2018), Islami Endekslerde Takvim Anomalisi: Ramazan Etkisi. Finans Politik \& Ekonomik Yorumlar, 55(645), 75-89.

Hayo, B. and Kutan, A. M. (2005). IMF-Related News and Emerging Financial Markets. Journal of International Money and Finance, 24, 11261142.

Irfan, A., Waheed, A., Namrah, A., Mohammed, M. E. (2017). Impact of Muslim Holy Days on Asian stock markets: An empirical evidence. Cogent Economics \& Finance, 5(1), 1-10.

Kahneman, D., Tversky, A. (1979). Prospect theory: An analysis of decisions under risk. Econometrica, 47, 313-327.

Kapusuzoglu, A. (2011). Herding in the Istanbul Stock Exchange (ISE): A Case of Behavioral Finance. African Journal of Business Research, 4(3), 53-67.

Karcioglu, R., Özer, N. (2017). BIST'de Haftanın Gunu ve Tatil Etkisi Anomalilerinin Getiri ve Oynaklık Uzerindeki Etkisinin Incelenmesi. Karadeniz Teknik Universitesi Sosyal Bilimler Enstitusu Sosyal Bilimler Dergisi, 7(14), 457-483.

Kayalidere, K. (2012). Hisse Senedi Piyasasında Suru Davranisi: IMKB'de Ampirik bir İnceleme. Isletme Arastirmalari Dergisi, 4(4), 77-94.

Kucuksille, E., Ozmutaf, N. M. (2015). Is There Ramadan Effect in Turkish Stock Market?, Uluslararasi Alanya Isletme Fakültesi Dergisi, 7(3), 105-110.

Lao, P., Singh, H. (2011). Herding behaviour in the Chinese and Indian stock markets. Journal of Asian Economics, 22(6), 495-506.

Lunde, A., Hansen, P. R. (2005). A forecast comparison of volatility models: does anything beat a GARCH (1,1)?. Journal of Applied Econometrics, 20(7), 873-889.

Lütkepohl, H. (2005). New Introduction to Multiple Time Series Analysis. New York: Springer.

Nelson, D. B. (1991). Conditional Heteroskedasticity in Asset Returns: A New Approach. Econometrica, 59(2), 347-370.

Oncü, M.A., Unal, A., Demirel, O. (2017). The Day of the Week Effect in Borsa Istanbul; A GARCH Model Analysis. Uluslararası Yönetim Iktisat ve Isletme Dergisi, 13(3), 521-534. 
Ozkan, N., Akbalik, M. (2018). Hicri Takvim Etkisi: Borsa Istanbul Gida-Icecek, Hizmetler ve Ulastırma Endekslerinde Yer Alan Paylar Uzerine Bir Arastırma, Journal of Yasar University, 13(49), 9-21.

Petros Messis Achilleas Zapranis, (2014). Herding behaviour and volatility in the Athens Stock Exchange. The Journal of Risk Finance, Vol. 15 Iss 5 pp. $572-590$

Seif, M., Docherty, P., Shamsuddin, A. (2017). Seasonal Anomalies in Advanced Stock Markets. The Quarterly Review of Economics and Finance, 66, 169-181.

Solakoğlu, M. N., Güvercin, A., Akkaş, M. E. (2016). The Impacts of Elections and Central Banks Meetings on Herding Behavior: Evidence from Borsa Istanbul, 20. Finans Sempozyumu, 19-22 October.

Tan, O. F. (2017). Ramadan Effect: Evidence from Borsa Istanbul. Marmara Universitesi Iktisadi ve Idari Bilimler Dergisi, 39(1), 239256 .

Thaler, R. (1987a). Anomalies The January Effect. Economic Perspectives, 1(1), 197-201.

Thaler, R. (1987b). Anomalies Seasonal Movements in Security Prices II: Weekend, Holiday, Turn of the Month, and Intraday Effects. Economic Perspectives, 1(2), 169-177.

Toraman, C., Öztosun, E., Colakoglu, E. (2017). Testing the Day-of-the-Week Anomaly for Sectoral Turkish Stock Market. International Journal of Business Management and Economic Research, 8(1), 862-871.

Trotter, W. (1916). Instincts of the Herd in Peace and War. London, T. Fisher Unwin Ltd, Retrieved from https://archive.org/details/instinctsofherdi00trot/page/n7

Ulusan, M., Hanci, G., Paksoy, M. (2013). Borsa Istanbul'da Ic ya da Dis Denetim Odaklı Bireyler Acisindan Bankacılık Hissele ri Bazında Suru Davranisinin Incelenmesi, 17. Finans Sempozyumu, 23-26 October

Ulusan Polat, M., Cilingirturk, Ah. M., Sumer Gogus, H. (2019). Do Calendar Anomalies Really Exist?: An Evidence from Borsa Istanbul, in (ed.) Pernsteiner. H, Sumer, H., Ulusan Polat, M., Behaviorial Finance, Linde Verlag, 249-281.

Urquhart, A., McGroarty, F. (2014). Calendar effects, market conditions and Adaptive Market Hypothesis: Evidence from long-run U.S. data. International Review of Financial Analysis, 35, 154-166.

Wang, D. (2008). Herd Behavior towards the Market Index: Evidence from 21 Financial Markets. IESE Business School Working Paper No. 776. Retrieved from https://ssrn.com/abstract=1316783 (Accessed: 04.05.2019).

Wu, H. X., Shea, E. Y. P. (2011). Explaining the China Puzzle: High Growth and Low Volatility in the Absence of Healty Financial Institutions, EcoMod2011 Conference, Azores, Portugal, June 29-July 1.

Yigiter, S. Y., Sari, S. S. (2016). 2008-2014 Yillari Arasinda BIST'de Haftanin Gunu Etkisi. C.Ü. Iktisadi ve Idari Bilimler Dergisi, 17(1), $287-301$. 